\title{
DIDACTIC CAPACITY OF SELECTED CZECH AND RUSSIAN ORGANIC CHEMISTRY TEXTBOOKS
}

\author{
WARTOŚĆ DYDAKTYCZNA WYBRANYCH CZESKICH \\ I ROSYJSKICH PODRĘCZNIKÓW CHEMII ORGANICZNEJ
}

\begin{abstract}
This article presents the results of analysis of Czech and Russian textbooks intended for organic chemistry teaching at upper secondary schools. In principle, the estimation of textbook didactic capacity is based on decomposition of the textbook content into a set of different objects and their subsequent frequency analysis. In this study, three Czech textbooks and three Russian textbooks were characterized by particular and total didactic capacity coefficients. The indifference of the calculated didactic capacities was tested by chi-square statistics at a level of significance $\alpha=0.05$. The results show that the selected Czech and Russian textbooks are not significantly different.
\end{abstract}

Keywords: didactic capacity, analysis of textbooks, educational mean, Czech and Russian textbooks, organic chemistry

\section{Introduction}

Currently, high-quality textbooks as a critical didactic resource remain a very valuable component of the educational process in every country, despite increasing utilization of modern technologies in the curriculum at primary, secondary and high schools [1-4]. Thanks to the information technologies, textbooks are not the only source of knowledge, but they still pervade in majority of school education activities. Because textbooks are to serve pedagogical objectives, they should be understandable to students and should provide a sufficient curriculum balance [5, 6]. Moreover, the role of textbooks is even broader since they are significantly associated with development of human personality as well as with building the national culture.

Nonetheless, publishers often offer an abundance of various textbooks rendering young teachers to face a difficult decision about which textbooks are most suitable for education [7]. In classroom, textbooks are very important didactic aids helping teachers and students to build systematically novel knowledge and skills $[8,9]$. It means that textbooks represent

\footnotetext{
${ }^{1}$ Department of Chemistry, Faculty of Sciences, University of Hradec Kralove, Rokitanskeho 62, Hradec Králové 50003, Czech Republic

${ }^{2}$ State Budget Professional Education Institution, Kosygina 17(3), Moscow 119334, Russia

*Corresponding authors: natalie.karaskova@uhk.cz, karel.kolar@uhk.cz
} 
a comprehensive and methodical complex of elementary information (i.e. core curriculum) for successful life. In fact, they are closely associated with other didactic aids, including computer technology (Fig. 1). The whole system of didactic aids is variable except from one steady basic element - textbooks $[10,11]$.

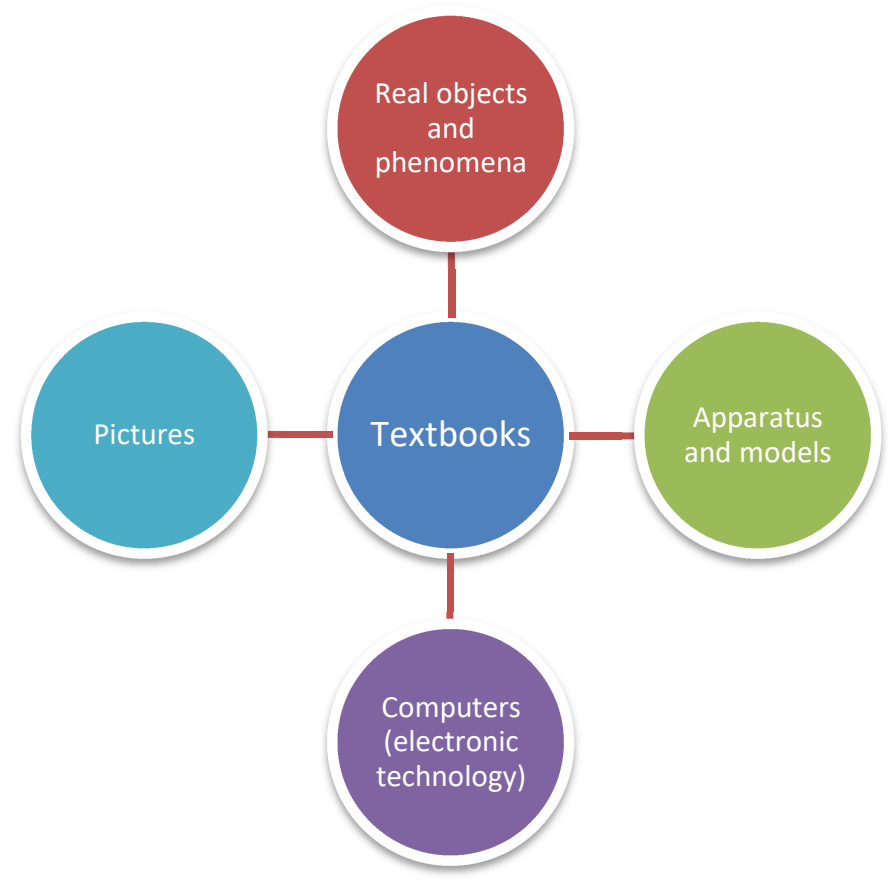

Fig. 1. System of teaching aids $[10,11]$

Crucial parts of the formal curriculum are elaborated introductory textbooks, which provide teachers with logically organized subject matter, methodical notes, motivating sections, tasks and evaluations. A proper textbook should present the subject in an easy way while keeping high technical accuracy. The language used should be appropriate for students at given educational level so that they can understand it correctly without extensive effort. Graphical form of textbooks should be maintained also at very high quality and artistic level taking into account suitable size of letters, highlighting important terms and definitions, using pictures, charts, photographs in high resolutions, etc.

Present research of textbooks focuses mainly on the analysis of the textbook form and content [12]. For instance, some authors [13] focused on the analysis of images, diagrams and nonverbal textbook content, or proposed a logical scheme for preparation of new schoolbooks with respect to their informational, systematizing, organizational, fixing, self-controlling, self-educational, scientific, integrating and social functions [14]. The important position of textbooks in school education is demonstrated by a number of studies that carried out complex textbook analyses and concluded that textbooks should reflect the last findings in pedagogical science, follow established educational principles 
and reforms, utilize modern styles of graphical presentation, and support self-educational functions and intensive feed-back [9, 15-17].

From the didactical point of view, the curriculum program is a hierarchically organized complex, which includes teaching aids, instructional texts and textbooks as a fundamental level (Fig. 2).

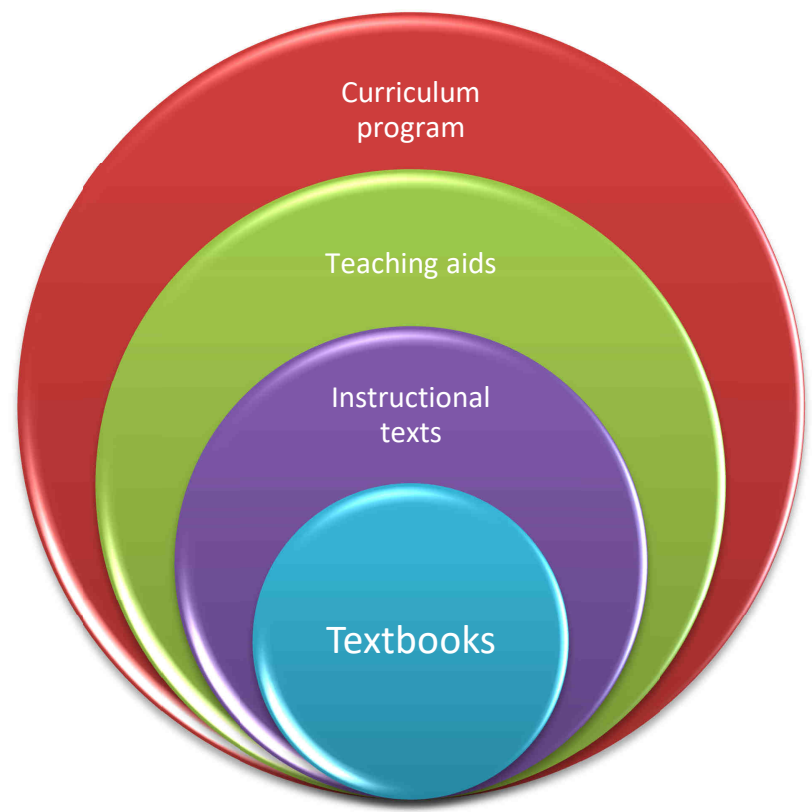

Fig. 2. System of educational construct [7]

In this paper, we have focused in particular on the analysis of Czech and Russian chemistry textbooks for upper secondary schools [18-21]. Presently in the Czech Republic as well as in Russia, the market of books offers many and various school textbooks, but only some of them meet requirements of the ministry of education or adequate governmental institutions. In the Czech Republic, the application of textbooks in the education process is not conditioned by any official approval clause by the Ministry of Education Youth and Sports. In this case, Czech teachers can freely choose textbooks for teaching. In the Russian Federation, the situation is not the same, Russian teachers must use textbooks approved by the Ministry of Education.

The central goal of this article is determining and quantifying the level of didactical capacity of the three selected Czech and three Russian textbooks for organic chemistry used at upper secondary school. These textbooks by Czech and Russian authors demonstrate specific didactical efforts developed over many years in the Czech Republic and Russia. To compare the chosen Czech and Russian textbooks intended for organic chemistry teaching, an algorithm for didactic capacity evaluation has been proposed, being based on determining special contingency tables and expressing their internal independence by $\chi^{2}$ statistics. The analytical method used in this study has been described in detail in the literature [7]. Its principle resides in decomposition of the textbook content into several 
component categories such as apparatus of subject presentation $(E I)$, apparatus of education control $(E I I)$, apparatus of orientation $(E I I I)$, and calculating frequencies of the individual elements. In textbooks, 36 different elements with verbal $(E v)$ and nonverbal $(E o)$ subcomponents, which contribute to the didactical capacity, can be generally identified. If all the components are utilized in a textbook, it can be considered within this approach as having full didactic capacity.

In the present work, null and alternative hypotheses were formulated and tested: the null hypothesis $\left(H_{0}\right)$ saying that the value of the total didactic capacity and its components (i.e. EI, EII, EIII, Eo, Ev) for the selected Czech and Russian textbooks are the same. The alternative hypothesis $H_{A}$ was stated that the total didactic capacity $(E)$ and its components of the selected Czech and Russian textbooks of organic chemistry are different.

\section{A brief history of Czech and Russian chemistry textbooks}

Written messages have been used for information transition between people since time immemorial. First text records are closely related with the development of speech and writing systems such as hieroglyphs, cuneiform, etc. Briefly, books played a very important role throughout the whole intellectual life of humankind. Since the invention of printing by Johannes Gutenberg, a mass production of books was enabled. Further important milestone in medieval education systems was associated with the reform of education and mandatory school education for all children between 6 and 12 years old enacted by the empress Maria Theresa. In connection with the education reform, schools and publishing houses for new school textbooks were set up, publishing the methodical manual for teachers by Johann Ignaz von Felbiger, who was the school consultant of the empress Maria Theresa. Up to now, the best-known publishing house established by Maria Theresa is the State Pedagogical Publisher in Czech Republic [22], which originally printed the school texts, later the scientific articles focusing on biology, chemistry and geography.

The first Czech school textbooks for chemistry teaching were written by Amerling [23]. In this period, the subject of chemistry was a part of physics. In 1849-1860, a school reform was proposed by professors Franz Seraphin Exner from Prague and Hermann Bonitz from Berlin who were oriented on secondary school and implemented individual subject of chemistry. Changes in education required reactions and elicited arising school chemistry textbooks, for example textbooks of authors Quadrat [24], Jahn and Prochazka [25], Cerveny [26] and Smetana [27]. The chemistry textbooks for basic schools were presented by practical guides while for upper secondary schools, theoretical reviews were prepared Huvarova [28].

In the period of Czech-Slovak Republic, the chemistry textbooks were adjusted and the authors of textbooks followed the pattern of German methodists, because national Czech didactics of chemistry did not exist at that time. The most famous authors of school books were Matzner, Masek, Nemecek, Krehlik, Kopa and Kouta. In their textbooks, organic chemistry is paid little attention, but the authors focused extensively on inorganic chemistry. Nonetheless, the chemistry experiments and visual illustrations were abundantly represented in those books [29]. After the Second World War, chemistry has become a mandatory subject at schools and the teaching texts were created with dominant implementation of deductive principles [30].

Chemistry and Czech chemistry textbooks were significantly influenced by Soviet scientists, such as D.I. Mendelejev, M.V. Lomonosov, A.M. Butlerov, N.N. Zinin, and 
A.P. Borodin [30]. These scientists were engaged not only in science, but they worked also on the methodology of teaching, development of didactics tools and school textbooks.

In Russia, chemistry teaching has begun to evolve since $18^{\text {th }}$ century thanks to M.V. Lomonosov, who was the first Russian author of textbooks of natural science. Nonetheless, Russian textbooks of chemistry were in the beginning translated from different languages. The first Russian school textbooks for university were presented by authors Sherer, Gize and Sceglov. Gize and Sceglov wrote also textbooks for universities, but they were rather used at schools. The first school textbooks were edited by Hess [31].

In Russia, further development of chemical textbooks was supported for example by Russian scientist born in Kazan - Butlerov, who published textbooks of organic chemistry and laid the foundations of organic compound definition. Among other known Russian chemists, V.N. Verchovskij gained important position since he was author of curricular program for chemistry teaching that become a valuable tool for teachers of chemistry and inspiration for teaching. The work of Verchovskij was oriented on interconnection of teaching and learning with daily life. Verchovskij frequently traveled in order to pass on his experience, and also elaborated a methodology of chemical experiments for teachers who worked in village schools. He was also a well-known author of illustrative didactic tools for chemistry teaching (e.g. models and appliances) [32].

\section{Qualitative and quantitative methods of textbooks' analyses}

Textbooks belong among material didactical tools which are intentionally created for application in education. Nonetheless, the structure of textbooks can be evaluated by various methods (e.g. qualitative, quantitative, structural, content, experimental, comparative techniques) to express their suitability or effectiveness in supporting students' learning [33]. Qualitative approaches for textbook evaluation maybe represented for example by questionnaires in which the respondents reply to a series of questions about the properties of textbooks. This method is also eloquently represented by textbook reviews. Qualitative methods are sometime very descriptive because they may involve interpretation and justification of the judgments, but on the other hand they are subjective and the results may significantly differ depending on the evaluator.

Quantitative methods are considered more objective since they minimize human bias factor influencing the measurements. The quantitative analytical tools for textbook evaluation can describe the text reading difficulty, the extent of textbooks, the textbook didactical capacity, syntactic text coherency, frequency of visual textbook components, etc. One of the most popular analytical method for textbook evaluation is determination of the text complexity which was introduced in 1980's by German scientist Käte Nestler and later modified by Prucha and Pluskal [7]. In brief, the text complexity $T$ of a textbook is given as summation of syntactic $T_{S}$ and semantic $T_{P}$ parts which represents, for example, average length of sentences or frequency of common and technical terms.

Another quantitative tool of textbook evaluation is didactic textbook capacity, which is based on frequency calculation of various verbal and nonverbal components [7]. This measure can be understood as an indicator of learning ease that the textbook provide to the student. The total didactic textbook capacity involves contributions of five particular didactic capacity coefficients and as quantitative measure it can be used for evaluation of group of textbooks, employing statistic for discrete values such $\chi^{2}$. It is matter of fact that textbooks with a high degree of didactic capacity facilitate students learning and 
significantly help teachers to organize education. In the following part Methodology and methods, analysis of didactic textbook capacity for three Czech and three Russian chemistry textbooks is described.

\section{Methodology and methods}

In this work, we focused on the analysis of didactic capacity, which assumes that textbooks are structured systems, composed of 36 components, each of them having its indispensable didactic function. To illustrate the method, the individual components of textbook didactic capacity can be divided into three prime groups based on their different didactic characteristics. Except from the coefficient of orientation, each of the groups is subdivided into verbal and nonverbal parts (Fig. 3) [7].

The principle of the presented method is to count all the present components of didactic capacity $E, E I, E I I, E I I I, E O$ and $E v$ in the chosen textbooks and to compare the frequencies by means of $\chi^{2}$ statistics for contingency tables.

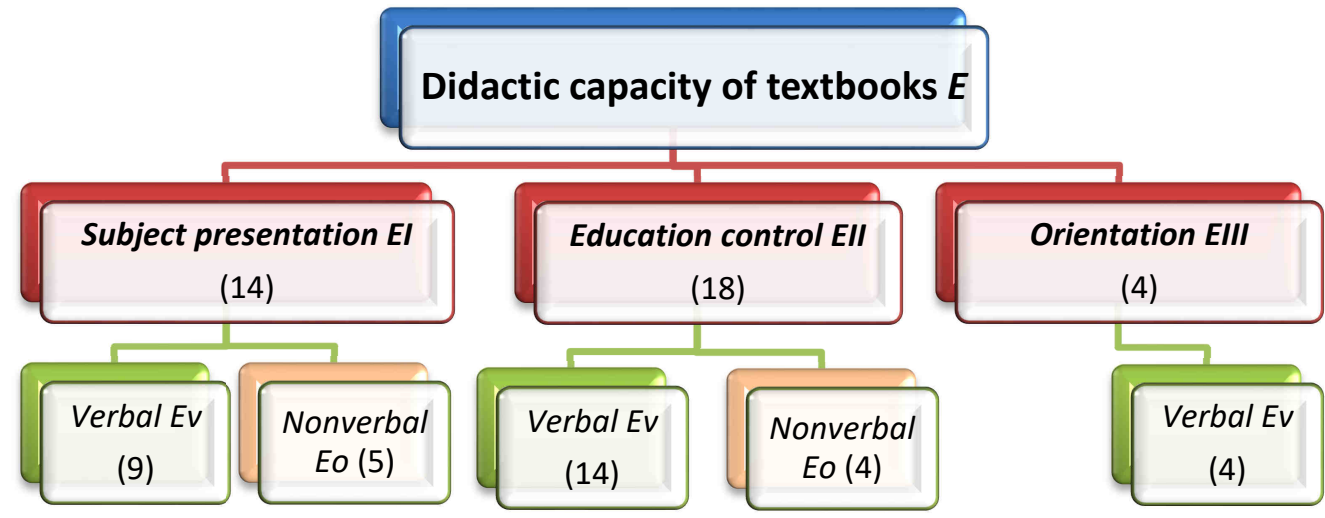

Fig. 3. Didactic capacity of textbooks, its sub-categories and number of components

Table 1

Apparatus of subject presentation and its components

\begin{tabular}{|c|c|}
\hline \multicolumn{2}{|c|}{ Subject presentation $E I$} \\
\hline Verbal components $E v$ & Nonverbal components $E o$ \\
\hline Explanation text simple & Artistic illustration \\
\hline Explanation text structured (overviews, schemes, tables, etc.) & Graphic illustration (schematics, models) \\
\hline Summary of the curriculum for the whole year & Photos \\
\hline Summary of the subject matter & Maps, cartograms, graphs, diagrams \\
\hline Summary of the curriculum for the previous year & Colorful images \\
\hline $\begin{array}{l}\text { Supplementary texts (statistical tables, etc.) } \\
\text { Notes and explanations } \\
\text { Subtext to pictures } \\
\text { Glossaries of terms, dictionary of foreign words }\end{array}$ & \\
\hline
\end{tabular}

The structure in Figure 3 represents the way how to establish components of didactic capacity $E I, E I I, E I I I, E v, E o$ and to deduce the total coefficient $E$ of the didactic capacity 
of textbooks. All the elements of EI, EII, EIII, Ev, Eo are summarized in Tables 1, 2 and 3 [7].

Apparatus of education control and its components

\begin{tabular}{|c|c|}
\hline \multicolumn{2}{|c|}{ Education control $E I I$} \\
\hline Verbal components $E v$ & Nonverbal components $E o$ \\
\hline Preface for pupils & \\
\hline Instructions for working with the textbooks & $\begin{array}{l}\text { Graphic symbols marking a certain part of the } \\
\text { text (rules, exercises, tasks) }\end{array}$ \\
\hline $\begin{array}{l}\text { Total stimulation (stimulation for thought, questions } \\
\text { before the total curriculum year) } \\
\text { Detailed stimulation (stimulation for thought, questions } \\
\text { before the total curriculum year, before and during } \\
\text { lessons) }\end{array}$ & $\begin{array}{l}\text { Use of special color for certain parts of the } \\
\text { verbal text } \\
\text { Use of special fonts (bold font, italics) for certain } \\
\text { parts of the verbal text }\end{array}$ \\
\hline $\begin{array}{l}\text { Differentiation level of curriculum/learning (obligatory, } \\
\text { optional) }\end{array}$ & $\begin{array}{l}\text { Use the front or back of textbook envelope for } \\
\text { the schematics and table }\end{array}$ \\
\hline Questions and task about topics & \\
\hline $\begin{array}{l}\text { Questions and task for the whole year } \\
\text { Questions and task for the previous year } \\
\text { Instructions for tasks of a more complex nature } \\
\text { (Instructional to experiments, laboratory works) } \\
\text { Topics for out-of-school activities (application) } \\
\text { Explicit expression of learning goal for students } \\
\text { Means or instruction for self-evaluation for students (tests) } \\
\text { Results of tasks and exercises } \\
\text { Links to other sources of information }\end{array}$ & \\
\hline
\end{tabular}

Apparatus of orientation and its components

\begin{tabular}{|l|}
\hline \multicolumn{1}{|c|}{ Orientation $\boldsymbol{E I I I}$} \\
\hline Verbal components $\boldsymbol{E} \boldsymbol{v}$ \\
\hline Content of a textbook \\
\hline Division of the textbooks into thematic blocks \\
\hline Marginalities, headings \\
\hline Index (name index, subject index, mixed index) \\
\hline
\end{tabular}

The method for calculation of didactic capacity can be described by the following sequence of steps:

1. The individual didactic components are identified in textbooks according to Prucha [7]. Prucha [7] recommended that the components of didactic capacity should be noted in special individual sheets. Sheets for the components of didactic capacity are prepared for each textbook involved in the study. At first, only components present in the textbooks are recorded, but not its frequency.

2. To count the total didactic capacity $(E)$ and its structural coefficients (EI, EII, EIII, Ev, $E o$ ), the formulas (1) are used:

$$
\begin{gathered}
E I=\frac{x}{14} \cdot 100, \quad E I I=\frac{x}{18} \cdot 100, \quad E I I I=\frac{x}{4} \cdot 100, \quad E o=\frac{x}{9} \cdot 100, \\
E v=\frac{x}{27} \cdot 100, \quad E=\frac{x}{36} \cdot 100
\end{gathered}
$$

where $E I$ is coefficient of the subject presentation; $E I I$ is coefficient of the education control; $E I I I$ is coefficient of orientation, $E v$ is coefficient of the verbal component, $E o$ is 
coefficient of the nonverbal component; $E$ is the total didactic capacity; $x$ is number of present components.

3. The coefficients of the didactic capacity given in the above formulas (1) are obtained as a percentage of the number of components in the textbook divided by the total number of components. Thus, the values range between 0-100\%. These coefficients describe didactic capacity of one textbook.

4. For comparison of two different textbooks, the observed element frequencies $x$ and their complements (i.e. max - $x$, see formulas (1)) are placed into contingency tables and analyzed by $\chi^{2}$ statistics. For comparison of two groups of textbooks, the corresponding frequencies $\mathrm{x}$ are summed up in each group of textbooks, put into the contingency tables and evaluated by $\chi^{2}$ statistics.

5. The found values of $\chi^{2}$ are compared with the tabulated values for given degree of freedom at significance level of $5 \%$.

6. The last step is interpretation of the resulting components of didactic capacity $(E, E I$, $E I I, E I I I, E o, E v)$. The found values give information about presence/absence of particular components of didactic capacity in the selected textbooks.

The benefit of the method of didactic capacity consists in its universal applicability in analyses of textbooks for various subjects, classes, and branches of study. If the didactic capacity terms $E, E I, E I I, E I I I, E o, E v$ should be evaluated for groups of textbooks, the frequencies of the individual elements' presence/absence are simply added within the group, placed into a contingency table and evaluated by $\chi^{2}$ statistics (Table 4$)$. The formula for calculating $\chi^{2}$ is given in equation (2):

$$
\chi^{2}=\frac{N(a d-b c)^{2}}{(a+b)(c+d)(b+d)(a+c)}
$$

where $N$ is sum of all elements. $a$ and $c$ are present elements of didactic capacity for textbooks A, $b$ and $d$ are absent elements of component didactic capacity for textbook B.

Table 4

Contingency table for the structural coefficients (EI, EII, EIII, Ev, Eo) and the total didactic capacity $E$

\begin{tabular}{|c|c|c|c|}
\hline Group & Present elements & Absent elements & Totals \\
\hline Textbooks A & $a$ & $b$ & $a+b$ \\
\hline Textbooks B & $c$ & $d$ & $c+d$ \\
\hline Totals & $a+c$ & $b+d$ & $a+b+c+d=N$ \\
\hline
\end{tabular}

This contingency table can be used for calculation of one type of elements for two textbooks, or for the sum of elements and two groups of books. If the probability that the found $\chi^{2}$ value for a given degree of freedom can result from distribution of independent standard normal random variables is less than 0.05 , we can reject the null hypothesis $\left(H_{0}\right)$ saying that textbooks A and textbooks B are of the same didactic capacity. Alternatively, in the case of $2 \times 2$ contingency table, the null hypothesis $\left(H_{0}\right)$ can be rejected if the calculated value of $\chi^{2}$ is greater than tabulated critical value of 3.841 for 1 degree of freedom at the level of $p=0.05$. To count the degree of freedom the following formulas (3) was used:

$$
f=(r-1)(s-1)
$$

where $f$ is degree of freedom, $r$ is number of lines, and $s$ is number of columns in the contingency table. 


\section{Results}

The present analysis of didactic capacity focused on organic chemistry textbooks used at upper secondary school. To evaluate the didactic capacity methodology, three Czech and three Russian organic chemistry textbooks for upper secondary school were selected. The main attribute of the selection of the school textbooks was the fact whether they have the approval clause, which is granted by the Ministry of Education, Youth and Sports (Ministerstvo skolstvi, mladeze a telovychovy, Czech Republic) or Ministry of Education and Science (Ministerstvo obrazovaniya i nauki) in the case of the Russian textbooks. Textbooks, which meet the requirements, are mentioned on the list, published and regularly renewed on the website of the Czech and Russian Ministry of Education www.msmt.cz and www.минобрнауки.рф. The two selected school Russian textbooks by Rudzitis and Feldman [21]; and Gabrielyan [19] are approved by the Ministry of Education and Science. Another criterion for selecting Russian textbook is the fact that the third school Russian textbook by Cvetkov [18] is the traditional book used at upper secondary school in the Soviet period. However, among the selected Czech organic chemistry textbooks, only textbook by Kolar et al. [20] fulfills the criterion. Selection of the textbooks by Marecek and Honza [34]; and by Vacik [29] was based on its frequent application at upper secondary school, as reported by Huvarova [28] and Klecka [33].

Summary of the components of didactic capacity (coefficient of subject presentation, coefficient of education control, coefficient of orientation, verbal and nonverbal coefficient) and the total didactic capacity of the studied textbooks are presented in Table 5.

Table 5

Summary of the didactic capacity components (coefficient of subject presentation - EI, coefficient of education control - EII, coefficient of orientation - EIII, nonverbal coefficient - Eo, verbal coefficient - Ev), the total didactic capacity - $E$, and the resulted values of $\chi^{2}$

\begin{tabular}{|c|c|c|c|c|c|c|c|}
\hline \multicolumn{2}{|c|}{ Names of textbooks } & $\boldsymbol{E I}[\%]$ & $\boldsymbol{E I I}[\%]$ & $\boldsymbol{E I I}[\%]$ & $\boldsymbol{E} \boldsymbol{[}[\%]$ & $\boldsymbol{E} \boldsymbol{0}[\%]$ & $\boldsymbol{E}[\%]$ \\
\hline \multirow{2}{*}{$\begin{array}{c}\text { Czech } \\
\text { textbooks }\end{array}$} & Kolar et al. & 64.29 & 55.55 & 100.00 & 77.78 & 59.26 & 63.89 \\
\cline { 2 - 8 } & Marecek and Honza & 42.86 & 27.77 & 75.00 & 33.33 & 40.74 & 38.89 \\
\cline { 2 - 8 } & Vacik & 64.29 & 27.77 & 75.00 & 77.78 & 37.04 & 47.22 \\
\hline \multirow{3}{*}{$\begin{array}{c}\text { Russian } \\
\text { textbooks }\end{array}$} & Cvetkov & 57.14 & 61.11 & 75.00 & 66.67 & 59.26 & 61.11 \\
\cline { 2 - 8 } & Gabrielyan & 50.00 & 38.89 & 100.00 & 77.78 & 40.74 & 50.00 \\
\hline & $\begin{array}{c}\text { Rudzitis and } \\
\text { Feldman }\end{array}$ & 57.14 & 66.66 & 75.00 & 77.78 & 59.26 & 63.89 \\
\hline & $\chi^{\mathbf{2}}$ & 0.044 & 4.566 & 0.000 & 0.622 & 0.0093 & 0.00349 \\
\hline
\end{tabular}

The analysis of the subject presentation EI of the chosen Czech [20, 29, 34] and Russian [18, 19, 21] organic chemistry textbooks used at upper secondary school is characterized in Figure 4.

The coefficients of subject presentation EI range from 42.86 to $64.29 \%$, in the following order: Kolar et al. [20], Vacik [29], Rudzitis and Feldman [21], Cvetkov [18], Gabrielyan [19], Marecek and Honza [34]. The subject presentation (EI) of Czech textbooks is the best scored in the textbook of Kolar et al. [32]. In the case of Russian textbooks, the values of the component EI found in Rudzitis and Feldman [21] and Soviet author Cvetkov [18] are better than those in the chemistry textbook for upper secondary school by Gabrielyan [19].

The result of comparison of the component of subject presentation of the selected Czech and Russian textbooks for the upper secondary school is described by $\chi^{2}$ value of 
0.044. The value of $\chi^{2}$ was compared with the tabulated critical value of 3.841 for 1 degree of freedom at significance level $\alpha=0.05$. Based on this result, we have accepted the null hypothesis, because the found value was less than the table critical value. Thus, the coefficient of subject presentation of the selected Czech and Russian organic chemistry textbooks used at upper secondary school are not significantly different.

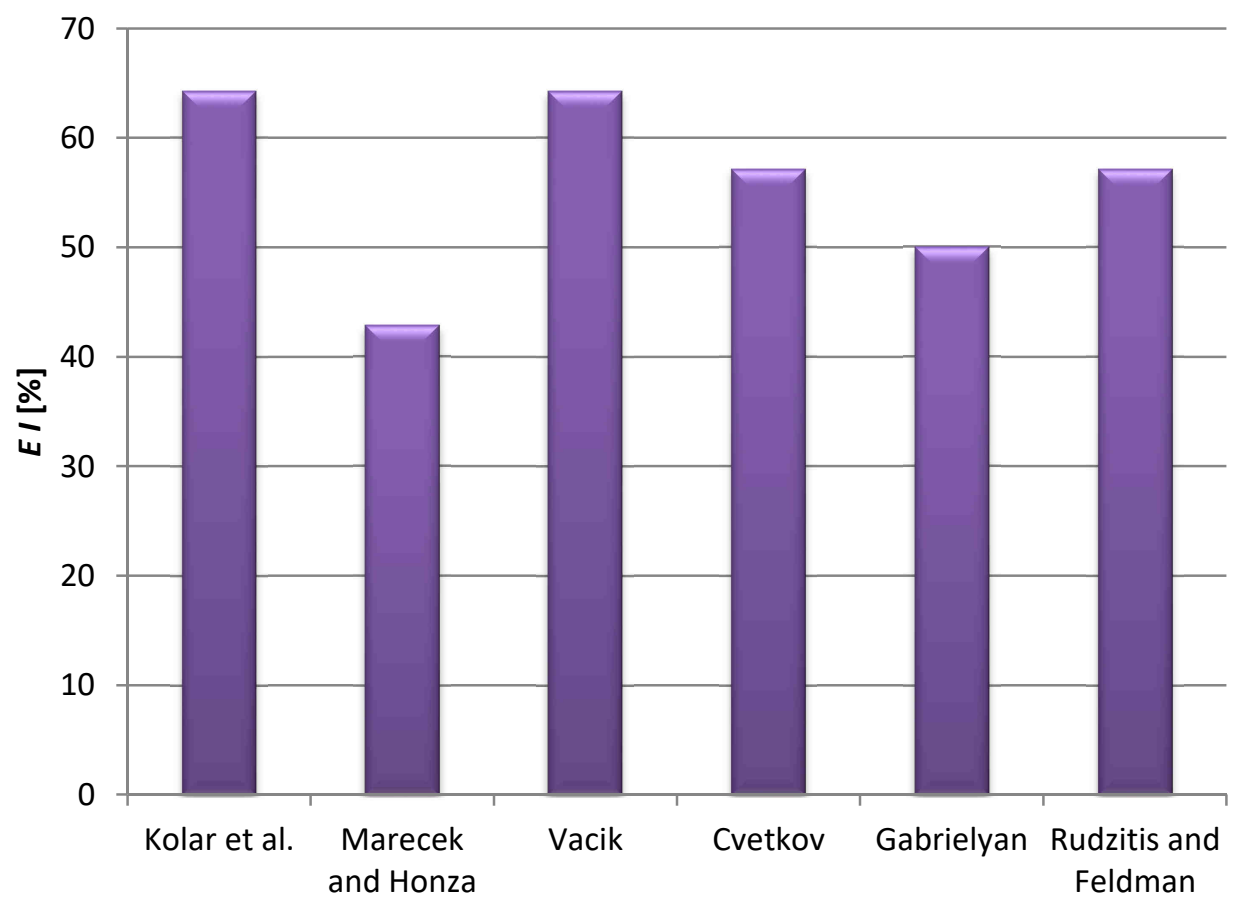

Fig. 4. The subject presentation (EI) of the selected Czech and Russian organic chemistry textbooks for upper secondary schools

In Figure 5, the values of the education control EII obtained in the analysis of the Czech and Russian textbooks used at the upper secondary school are presented.

From the presented results of education control EII, we can easily see that Czech textbook by Kolar et al. [20] gained $E I I=55.55 \%$, Marecek and Honza [34]; and Vacik [29] $E I I=27.77 \%$. In the case of the Russian textbook, the highest coefficient of education control is reached by Rudzitis and Feldman [21], with score $E I I=66.66 \%$.

The results of the $\chi^{2}$ for the coefficient of education control assumed the value of 4.566. If we compare the value $\chi^{2}$ with the tabulated critical value for 1 degree freedom at the significance level $\alpha=0.05$, we can reject the null hypothesis and accept the alternative hypothesis. The accepted alternative hypothesis is following: a statistically significant difference between coefficient of education control of the selected Czech and Russian organic chemistry textbooks can be postulated. 


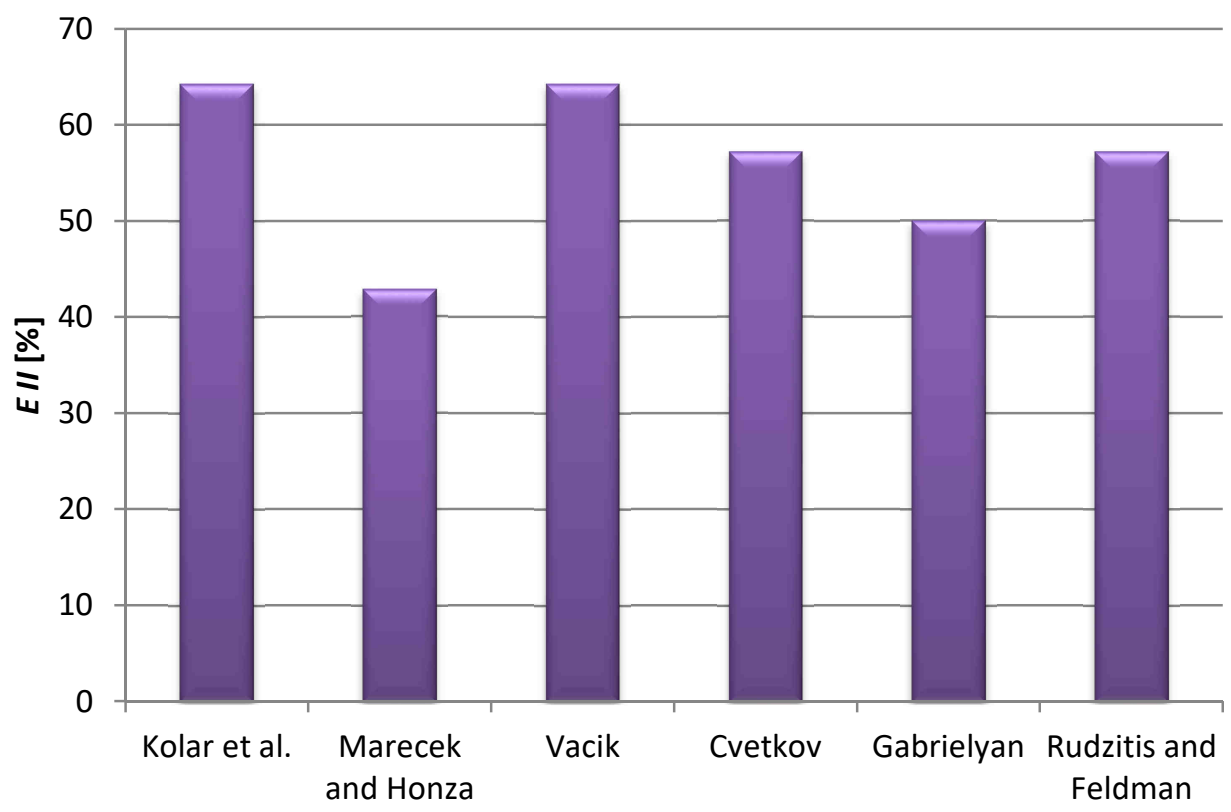

Fig. 5. Overview of the education control coefficients EII of the selected Czech and Russian organic chemistry textbooks for upper secondary schools

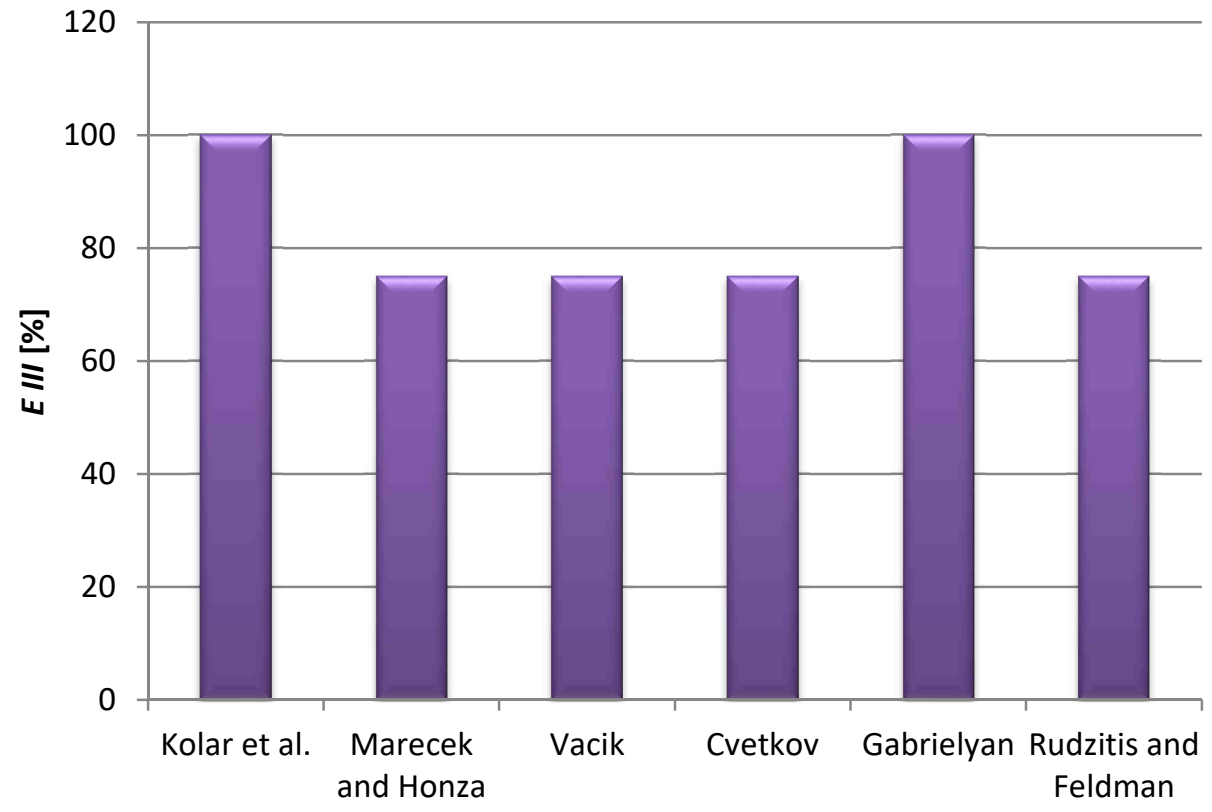

Fig. 6. Coefficients of orientation EIII for the selected Czech and Russian chemistry textbooks for upper secondary schools 
The coefficients of orientation for the selected textbooks by Czech authors [20, 29, 34] and Russian authors $[18,19,21]$ used at chemistry teaching in upper secondary school are outlined in Figure 6.

The coefficients of orientation EIII of the selected Czech and Russian chemistry textbooks used at upper secondary schools range from 75 to $100 \%$. The chemistry textbook by Kolar et al. [20] gained EIII $=100 \%$, the textbook by Vacik [29] gained $E I I I=75 \%$ and the textbook by Marecek and Honza [34] gained EIII $=75 \%$. The textbooks of Russian authors: Rudzitis and Feldman [27] scored with EIII $=75 \%$, Cvetkov [18] scored with $E I I I=75 \%$ and Gabrielyan [19] gained $E I I I=100 \%$.

The found value of $\chi^{2}$ for the coefficient of orientation was 0.000 . This value was compared with table critical value gained 3.841 for 1 degree freedom at significance level of $\alpha=0.05$. This result means that we can rejected the alternative hypothesis and accept the null hypothesis. This result implies that the coefficients of orientation of the select Czech and Russian textbooks are again not significantly different.

The verbal coefficients of the selected Czech and Russian textbooks used in organic chemistry teaching at upper secondary schools are shown in Figure 7.

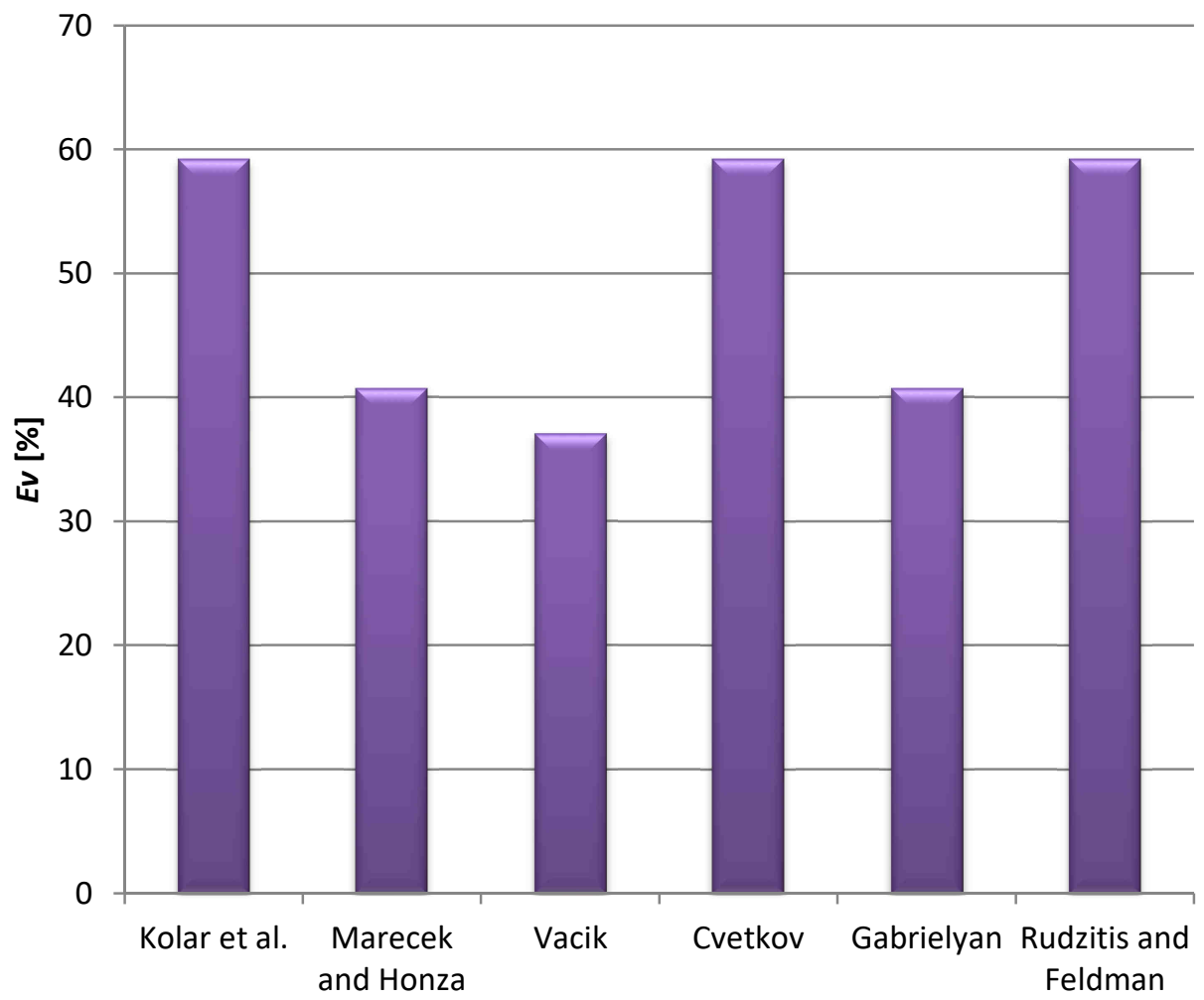

Fig. 7. Verbal coefficients $E v$ of the Czech and Russian chemistry textbooks for upper secondary schools 
The found values of verbal coefficients are as follows: the textbook by Kolar et al. [20] gained 59.26 \%, Marecek and Honza [34] $40.74 \%$ and Vacik [29] $37.04 \%$. The Russian textbooks were characterized by values of verbal coefficient in following order: Cvetkov [18] $E v=59.26 \%$, Rudzitis and Feldman [27] $E v=59.26 \%$ and the lowest value was ascribed to Gabrielyan [19] with score $E v=40.74 \%$.

The result of $\chi^{2}$ for verbal coefficient reached the value of 0.0093 . Comparing the found value with table critical one for 1 degree freedom at significance level $\alpha=0.05$, we can accept the null hypothesis and reject the alternative hypothesis. This means in other words that the verbal coefficients of the chosen Czech and Russian textbooks used at organic chemistry teaching are practically the same.

The last component of didactic capacity is the nonverbal coefficient. The values for the selected Czech and Russian textbooks assigned for organic chemistry teaching at upper secondary schools are demonstrated in Figure 8.

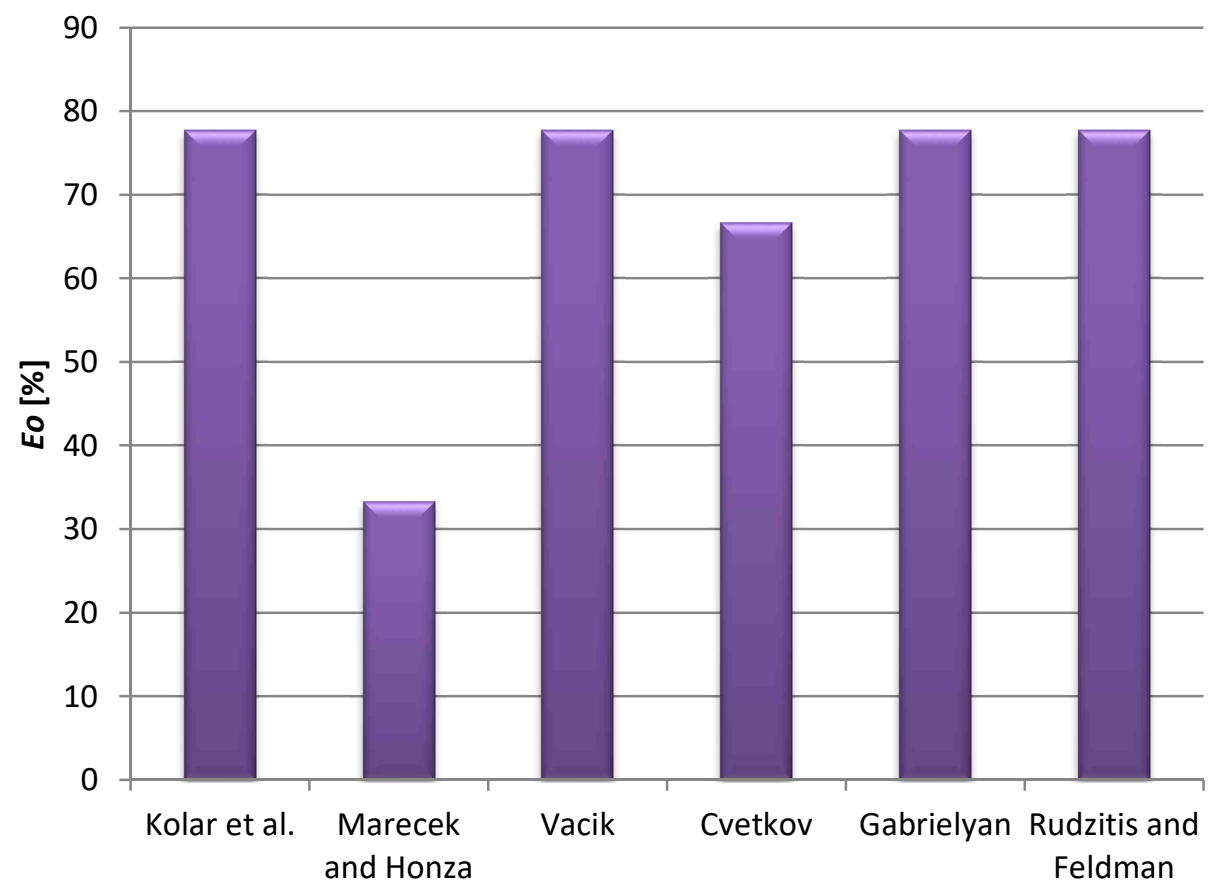

Fig. 8. The nonverbal coefficients of the selected Czech and Russian organic chemistry textbooks for upper secondary schools

Regarding the Czech textbooks, the highest values were reached by textbooks by Kolar [20] and Vacik [29] with Eo $=77.78 \%$. The Marecek and Honza's [34] textbook gained only $E o=33.33 \%$. Among the Russian textbooks, the values fluctuated from $66.67 \%$ to $77.78 \%$ in following order: Cvetkov [18] obtained $66.67 \%$, Rudzitis \& Feldman [21] and Gabrielyan [19] both obtained $77.78 \%$. 
The found value of $\chi^{2}$ for the nonverbal coefficient equaled 0.622 . The resulted value was less than the critical table value for 1 degree freedom at significance level $\alpha=0.05$. The small value means that the null hypothesis should not be rejected. Again it was confirmed that the select Czech and Russian organic chemistry textbooks used at upper secondary school are not significantly different.

The analyses of the total didactic capacity $E$ of the selected Czech $[20,29,34]$ and Russian $[18,19,21]$ organic chemistry textbooks for secondary school are depicted in Figure 9.

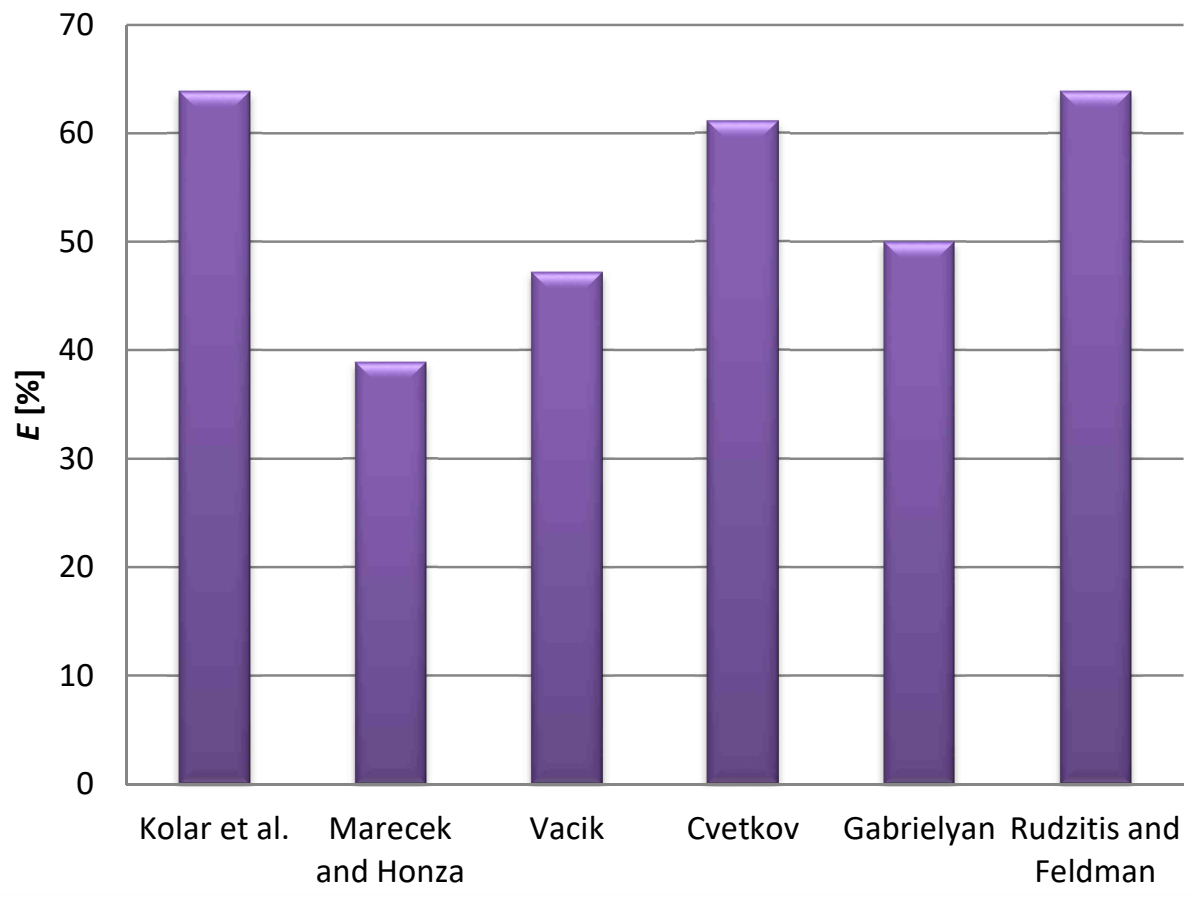

Fig. 9. Characterization of the total didactic capacities $E$ of the selected Czech and Russian organic chemistry textbooks for upper secondary schools

The Czech textbook by Kolar et al. [20] was scored with $E=63.89 \%$ and that by Marecek and Honza [34] with $E=38.89 \%$. The Russian textbooks by Gabrielyan [19] gained $E=50.00 \%$ and by Rudzitis and Feldman [21] $E=63.89 \%$. From the presented results, it can be easily deduced that the top scoring Czech textbook of organic chemistry is the one by Kolar et al. [20], the second is by Vacik [31], and third is by Marecek and Honza [34]. In the case of the Russian high school chemistry textbooks, the one by Rudzitis and Feldman [21] is the best didactically equipped, with the coefficient of the total didactic capacity $E$ equal to the value of the Czech textbook by Kolar et al. [20] The Czech secondary school textbooks by authors Marecek and Honza [34] seem to not be ideally didactically equipped, although its utilization in Czech schools is widespread. 
The comparison of the total didactic capacity $E$ of the selected Russian and Czech secondary school chemistry textbooks was performed using $\chi^{2}$ statistics. However, the resulting $\chi^{2}=0.0349$ does not exceed the tabulated value on the level of significance $\alpha=0.05$ for 1 degree of freedom 3.841 , which means that there is no statistically significant difference between the two groups. Thus, the $H_{0}$ cannot be rejected in this case.

\section{Conclusion}

The presented analysis provides an overview of the total didactic capacity $(E)$ and components of didactic capacity $(E I, E I I, E I I I, E O, E v)$ of the selected Czech and Russian secondary school textbooks for organic chemistry and their mutual comparison by $\chi^{2}$ statistics. The research has informative character for Russian and Czech young as well as experienced teachers of organic chemistry at upper secondary school. The study shows that the most didactically equipped Czech textbook of organic chemistry is the grammar school textbook by Kolar et al. [20]. Among the Czech textbooks, the least didactic capacity was found for the school textbook of Marecek and Honza [34]. However, it should be noted that the textbook of Marecek and Honza [23] is often used at Czech upper schools. The best didactically equipped Russian textbooks was the one by Rudzitis and Feldman [21]. If we compare the Czech and Russian textbooks of organic chemistry by the method for didactic capacity based on contingency table and $\chi^{2}$ statistics, we can conclude that there is no significant difference between these two groups of textbooks.

\section{Acknowledgements}

The research has been supported by Specific Research Project of Faculty of Science, University of Hradec Kralove, No. 2103, 2017.

\section{References}

[1] Baek E-O, Monaghan J. Journey to textbook affordability: An investigation of students' use of a Textbooks at multiple campuses. Int Rev Res Open Distributed Learning. 2013;14:1-26. DOI: 10.19173/irrodl.v14i3.1237.

[2] Gurung RAR, Martin CR. Predicting textbook reading. Teach Psychology. 2011;38:22-8. DOI: 10.1177/0098628310390913.

[3] Kim JHY, Jung HY. South Korean digital textbook project. Computers in the Schools. 2010;27:247-65. DOI: $10.1080 / 07380569.2010 .523887$.

[4] Sunarko V, Haro N, Sitorus IT, Sitorus P A, Saragih E. A content analysis of "Joyful" English textbook for Primary Grade II. JEE. 2019;4:77-88. DOI: 10.31327/jee.v4i2.1107.

[5] Abd-El-Khalick F, Myers JY, Summers R, Brunner J, Waight N, Wahbeh N, et al. A longitudinal analysis of the extent and manner of representations of nature of science in U.S. high school biology and physics textbooks. J Res Sci Teach. 2017;54:82-120. DOI: 10.1002/tea.21339.

[6] Birema A-M, Schwartz RS, Gill SA. To what extent does current scientific research and textbooks content align? A methodology and case study. J Res Sci Teaching. 2017; 54:1097-118. DOI: 10.1002/tea.21399.

[7] Průcha J. Učebnice: Teorie analýzy edukačního media (Textbooks: Theory of educational media analysis). Brno: Paido; 1998. ISBN: 8085931494.

[8] Devetak I, Vogrinc J. The Criteria for Evaluating the Quality of the Science Textbooks. Critical Analysis of Science Textbooks. Dordrecht: Springer Netherlands; 2013. ISBN: 9789400741676.

[9] Vesterinen V-M, Aksela M, Lavonen J. Quantitative analysis of representations of nature of science in nordic upper secondary school textbooks using framework of analysis based on philosophy of chemistry. Sci Educ. 2013; 22:1839-55. DOI: 10.1007/s11191-011-9400-1.

[10] Janoušková E. Vztah úrovně didaktické vybavenosti a míry obtížnosti textu současných učebnic (Relationship between the level of didactic capacity and the degree of text difficulty of contemporary textbooks). Praha: Pedagogical orientation. 2009;19:56-72. 
[11] Maňák J, Knecht P. Hodnocení učebnic (Evaluation of texbooks). Brno: Paido; 2007. ISBN: 9788073151485.

[12] Zierer K. Didactics textbooks in Germany and the USA: A study of eclecticism, selection and integration. Res Comparative Internat Educ. 2011;62:147-60. DOI: 10.2304/rcie.2011.6.2.147.

[13] Friesen N. The past and likely future of an educational form: A textbook case. Educational Res. 2013;42:498-508. DOI: 10.3102/0013189X13513535.

[14] Ibragimov ID, Dusenko SV, Khairulina ER, Tikhonova NV, Yevgrafova OG. Recommendations on the textbooks creation as information and teaching tools of education management. Int Elect $\mathrm{J}$ Math Ed. 2016;11:33-446. Available from: https://www.iejme.com/article/recommendations-on-the-textbookscreation-as-information-and-teaching-tools-of-education-management.

[15] Berry T, Cook L, Hill N, Stevens K. An exploratory analysis of textbook usage and study habits: Misperceptions and barriers to success. College Teach. 2010;59:31-9. DOI: $10.1080 / 87567555.2010 .509376$.

[16] Foster S. Dominant traditions in international textbook research and revision. Education Inquiry. 2016;2:5-20. DOI: 10.3402/edui.v2i1.21959.

[17] Mohd SH. EFL Textbook analysis: A case study. Language and Literacy. 2012;14:27-45. DOI: 10.20360/G2HP4J.

[18] Cvetkov LA. Organicheskaya khimiya: uchebnik dlya uchashchikhsya 10-11 klassov (Organic chemistry: textbook for students in grades 10-11). Moscow: Gumanitarnyj izdatelskij tsentr Vlados; 2013. ISBN: 9785691003660 .

[19] Gabrielyan OO. Khimiya: 10 klass, 18-e (Chemistry: Grade 10, 18th). Moscow: Drofa; 2011. ISBN: 978535814007-3.

[20] Kolář K, Kodíček M. Chemie II. pro gymnázia - organická chemie a biochemie (Chemistry II. For grammar schools - organic chemistry and biochemistry). Praha: SPN - Pedagogical publisher; 2005. ISBN: 8072352830.

[21] Rudzitis GE, Feldman FG. Khimiya: Organicheskaya khimiya 10 klass (Chemistry: Organic Chemistry Grade 10). Moscow: Prosveschenije; 2012. ISBN: 9785090265164.

[22] Viehhauser M. Das Schulwesen aber ist und bleibt allezeit ein politikum (But the school system is and always will be a political issue): The Felbiger General School Ordinance and School Reform in the Eighteenth-Century Habsburg Monarchy. Westberg J, Boser L, Brühwiler I, editors. School Acts and the Rise of Mass Schooling. Cham: Springer International Publishing; 2019. ISBN: 9783030135690.

[23] Macleod M, Sumillera RG, Surman J, Smirnova E. Language as a Scientific Tool: Shaping Scientific Language Across Time and National Tradition. New York: Routledge, Taylor Francis Group; 2016. ISBN: 9781138101050.

[24] Quadrát BB. Základové chemie: K užívání na nižších reálkách (Basic chemistry: For the use in lower secondary schools). Brno: Tiskem Karla Winikera; 1862.

[25] Jahn Z, Procházka P. Chemie organická čili chemie sloučenin uhlíkových (Organic chemistry or chemistry of carbon compounds). Praha; 1878.

[26] Červený A. Základové lučby hospodářské (Basics of homestead chemistry). Praha; 1868.

[27] Smetana FJ. Počátkové silozpytu čili fysiky pro nižší gymnasia a reálky (Beginning of "silozpyt" or physics for lower gymnasiums and secondary schools). Praha: J. G. Calve. 1852.

[28] Huvarová M. Nejpoužívanější stř̌edoškolské učebnice chemie na gymnáziích (The most used high school chemistry textbooks at grammar schools). Olomouc: Palacký University Olomouc; 2010.

[29] Vacík J. Přehled středoškolské chemie (Overview of high school chemistry). Praha: SPN - Pedagogical publisher; 1999. ISBN: 9788085937084.

[30] Čtrnáctová H. Učební úlohy v chemii (Learning tasks in chemistry). Praha: Karolinum; 2009. ISBN: 8071847070.

[31] Teleshov VS. Osnaščenije kabinětov khimii v Rossijskoj Imperii XIX - načale XX vv (Equipping classrooms of chemistry in the Russian Empire in XIX - early XX centuries). St. Petersburg: Gamtamokslinis ugdymas bendrojo ugdymo mokykloje. 2017;23:125-36.

[32] Karásková N, Kolář K. Vadim Nikandrovich Verkhovskij i jego wkład na rzecz edukacji chemicznej (Vadim Nikandrovich Verkhovskij and his contribution to chemical education). In: Co w dydaktykach nauk przyrodniczych ocalić od zapomnienia? (What to save in natural science didactics from forgetting?) Kraków: Uniwersytet Pedagogiczny w Krakowie; 2015. ISBN: 9788372719676.

[33] Klečka M. Teorie a praxe tvorby učebnic chemie pro střední školy (Theory and practice of creating chemistry textbooks for secondary schools). Praha: Charles University; 2011.

[34] Mareček A, Honza J. Chemie pro čtyřletá gymnázia - 3 díl (Chemistry for four-year grammar schools $3^{\text {rd }}$ volume). Olomouc: Olomouc Publisher; 2000. ISBN: 9788090240261. 